\title{
PENGARUH MEFENOKSAM DAN Trichoderma sp. TERHADAP PENYAKIT BULAI DAN PERTUMBUHAN TANAMAN JAGUNG
}

\section{EFFECT OF MEFENOXAM AND Trichoderma sp. OF DOWNY MILDEW AND THE GROWTH OF CORN PLANT}

\author{
Elsa Wulandari*, Joko Prasetyo, Muhammad Nurdin dan Tri Maryono \\ Jurusan Agroteknologi Fakultas Pertanian Universitas Lampung, Bandar Lampung, Indonesia \\ Email: ewulandari009@gmail.com \\ * Corresponding Author, Diterima: 15 Okt. 2021 , Direvisi: 23 Des. 2021 , Disetujui: 11 Jan. 2022
}

\begin{abstract}
One of the obstacles in the cultivation of maize is downy mildew caused by the fungus Peronosclerospora sp. Typical symptoms of downy mildew in corn plants are chlorotic that extends parallel to the leaf bones, the growth of the affected plants is stunted, and in the morning there are signs of disease in the form of white flour under the leaf surface. One of the active fungicides that can be used to control downy mildew is mefenoxam. The purpose of this study was to determine the effect of mefenoxam, Trichoderma sp. to downy mildew disease intensity and maize plant growth, and knowing the interaction between mefenoxam and Trichoderma sp. to downy mildew disease intensity and corn plant growth.This study used a randomized block design which was arranged factorial with 2 factors with three replications. The first factor used was fungicide, while the second factor was Trichoderma sp. The results showed that mefenoxam fungicide treatment could reduce the downy mildew.
\end{abstract}

Keywords: Downy mildew occurrence, downy mildew severity, Peronosclerospora sp., Zea mays L.

\section{ABSTRAK}

Salah satu kendala dalam budidaya tanaman jagung adalah penyakit bulai yang disebabkan oleh jamur Peronosclerospora sp. Gejala khas penyakit bulai pada tanaman jagung berupa gejala klorotis memanjang sejajar tulang daun, pertumbuhan tanaman yang terserang terhambat, dan pada pagi hari terlihat tanda penyakit berupa tepung putih di bawah permukaan daun. Salah satu bahan aktif fungisida yang dapat digunakan untuk mengendalikan penyakit bulai adalah mefenoksam dan salah satu antagonis yang dapat digunakan untuk mengendalikan penyakit ini adalah Trichoderma sp. Tujuan dilakukannya penelitian ini yaitu mengetahui pengaruh mefenoksam, Trichoderma sp. terhadap intensitas penyakit bulai dan pertumbuhan tanaman jagung, dan mengetahui adanya interaksi mefenoksam dan Trichoderma sp. terhadap intensitas penyakit bulai dan pertumbuhan tanaman jagung. Penelitian ini menggunakan Rancangan Acak Kelompok (RAK) yang disusun secara faktorial dengan 2 faktor dengan tiga kali ulangan. Faktor pertama yang digunakan yaitu fungisida sedangkan faktor kedua Trichoderma sp. Hasil penelitian menunjukkan bahwa perlakuan fungisida mefenoksam dapat menekan keterjadian dan keparahan penyakit.

Kata kunci: Keterjadian penyakit bulai, keparahan penyakit bulai, Peronosclerospora sp., Zea mays L.

\section{PENDAHULUAN}

Jagung merupakan komoditas palawija yang dapat dijadikan salah satu komoditas unggulan agribisnis. Tanaman ini berperan dalam perekonomian nasional serta mempunyai peluang untuk dikembangkan sebagai sumber utama karbohidrat. Pengembangan usaha tani jagung memiliki peran yang cukup penting dan strategis dalam pembangunan nasional dan regional, serta terhadap ketahanan pangan dan perbaikan perekonomian (Muhammad, 2014).

Lampung merupakan salah satu daerah penghasil jagung di Indonesia. Menurut Badan Pusat Statistik (2017) luas tanaman jagung di Lampung mencapai 482.607 hektar dengan produksi 2.518 .894 ton. Produktivitas jagung di Lampung masih berada pada kisaran 50 kuintal/ hektar sedangkan potensi jagung optimal sebesar 
100 kuintal/hektar. Hal ini menunjukkan produktivitas jagung di Lampung masih jauh dari potensi optimal produksi tanaman jagung.

Salah satu kendala dalam budidaya tanaman jagung adalah penyakit bulai yang disebabkan oleh jamur Peronosclerospora sp. Gejala khas penyakit bulai pada tanaman jagung berupa klorotis memanjang sejajar tulang daun, pertumbuhan tanaman yang terserang terhambat, dan pada pagi hari terdapat tanda penyakit berupa lapisan tepung putih dibawah permukaan daun (Jatnika dkk., 2013). Menurut Semangun (2004), penyakit bulai pada pertanaman jagung dapat menurunkan hasil produksi sebesar $90 \%$.

Penggunaan fungisida kimia untuk pengendalian penyakit bulai masih menjadi pilihan utama para petani. Selain itu, saat ini fungisida banyak digunakan dalam bentuk seed treatment. Metalaksil merupakan bahan aktif fungisida yang sering digunakan oleh petani. Akan tetapi, penggunaan bahan aktif ini secara terus - menerus dapat menyebabkan terjadinya resistensi pada patogen penyebab penyakit bulai (Burhanuddin, 2009). Oleh karena itu, perlu dicari alternative lain yang efektif.

Salah satu bahan aktif fungisida yang dapat digunakan untuk mengendalikan penyakit bulai adalah mefenoksam. Fungisida ini bersifat sistemik dan berbentuk cairan. Menurut Monkiedje et. al. (2002) dalam Gomez et. al. (2015), mefenoksam (R-metalaxyl) adalah enansiomer-R dari fungisida metalaksil dan telah digunakan sebagai perawatan benih. Fungisida ini dapat diaplikasikan pada tanah dengan metode seed treatment dan dengan metode penyemprotan pada daun.

Salah satu agensia hayati yang digunakan untuk menekan penyakit tanaman yaitu Trichoderma sp. Menurut Harman et al. (2004) aplikasi Trichoderma sp. pada rizosfer tanaman jagung diduga dapat memicu jumlah enzim peroksidase dan enzim polifenoloksidase tanaman. Enzim peroksidase berperan dalam penguatan dinding sel tanaman sehingga dapat menghambat infeksi patogen.

\section{BAHAN DAN METODE}

Penelitian ini dilakukan dari Januari 2020 sampai dengan Oktober 2020 di Fakultas Pertanian dan Laboratorium Ilmu Penyakit Tumbuhan, Jurusan Proteksi Tanaman, Fakultas Pertanian Universitas Lampung. Penelitian ini menggunakan metode Rancangan Acak Kelompok (RAK) yang disusun secara faktorial dengan 2 faktor. Faktor pertama adalah aplikasi fungisida berbahan aktif mefenoksam dengan 2 perlakuan yaitu $\mathrm{F}_{0}=$ tanpa fungisida mefenoksam dan $\mathrm{F}_{1}=$ menggunakan fungisida mefenoksam. Faktor kedua adalah perlakuan Trichoderma sp. yang terdiri dari 4 level yaitu $\mathrm{T}_{0}=$ tanpa Trichoderma sp., $\mathrm{T}_{1}=$ Trichoderma sp. dengan kerapatan spora $10^{5}$ spora $/ \mathrm{ml}, \mathrm{T}_{2}=$ Trichoderma $\mathrm{sp}$. dengan kerapatan spora $10^{6} \mathrm{spora} / \mathrm{ml}$ dan $\mathrm{T}_{3}=$ Trichoderma sp.dengan kerapatan spora $10^{7} \mathrm{spora} / \mathrm{ml}$. Penelitian ini terdiri dari 8 perlakuan dan 3 ulangan sehingga terdapat 24 satuan percobaan yang digunakan. Berikut merupakan tata letak percobaan dengan penentuan ulangan diacak dengan menggunakan gulungan kertas yang ditempatkan secara acak (Gambar 1).

Pengamatan dan pengumpulan data dilakukan selama 45 hari. Parameter yang diamati adalah

\begin{tabular}{|l|l|l|l|}
\multicolumn{1}{|l}{ Kelompok I } & \multicolumn{1}{l}{ Kelompok II } & \multicolumn{1}{l}{ Kelompok III } \\
\hline F0T2 & \multicolumn{1}{|l|}{ F0T3 } & F1T1 \\
\hline F0T3 & F0T2 & F1T2 \\
\hline F1T0 & F1T0 & F0T1 \\
\hline F0T1 & F0T1 & F0T3 \\
\hline F1T3 & F1T2 & F1T0 \\
\hline F1T1 & F1T1 \\
\hline F1T2 & F1T3 & F0T0 \\
\hline F0T0 & F0T0 \\
\hline
\end{tabular}

Gambar 1. Tata Letak Percobaan

Keterangan: $F_{0}=$ Tanpa fungisida, $F_{1}=$ Menggunakan fungisida mefenoksam, $\mathrm{T}_{0}=$ Tanpa Trichoderma $\mathrm{sp} ., \mathrm{T}_{1}=$ Trichoderma $\mathrm{sp}$. kerapatan spora $10^{5}$ spora $/ \mathrm{ml}, \mathrm{T}_{2}=$ Trichoderma sp. kerapatan $10^{6} \mathrm{spora} / \mathrm{ml}$, $\mathrm{T}_{3}=$ Trichoderma $\mathrm{sp}$. kerapatan $10^{7} \mathrm{spora} / \mathrm{ml}$.

Tabel 1. Kategori Penyakit Dalam Pengamatan

\begin{tabular}{cl}
\hline Skor & \multicolumn{1}{c}{ Keterangan } \\
\hline 0 & Tidak ada gejala \\
\hline 1 & $\begin{array}{l}\text { Gejala timbul sampai } \leq 10 \% \text { bagian } \\
\text { daun }\end{array}$ \\
\hline 2 & $\begin{array}{l}\text { Gejala terjadi pada }>10 \% \text { sampai } \leq \\
25 \% \text { bagian daun }\end{array}$ \\
\hline 3 & $\begin{array}{l}\text { Gejala terjadi pada } \geq 25 \% \text { sampai } \leq \\
50 \% \text { bagian daun }\end{array}$ \\
\hline 4 & $\begin{array}{l}\text { Gejala terjadi pada } \geq 50 \% \text { atau daun } \\
\text { mati }\end{array}$ \\
\hline
\end{tabular}


masa inkubasi, intensitas penyakit bulai dan pertumbuhan tanaman jagung. Masa inkubasi merupakan selang waktu dari saat inokulasi sampai munculnya gejala penyakit untuk pertama kalinya pada tanaman. Masa inkubasi diamati setiap hari sampai timbulnya gejala awal penyakit bulai.

Menurut Ginting (2013), intensitas penyakit dapat dilihat dalam dua bentuk yaitu keterjadian dan keparahan penyakit. Keterjadian penyakit dihitung dengan menggunakan rumus sebagai berikut:

$$
\mathrm{KP}=\frac{n}{N} X 100 \%
$$

Keterangan : KP = Keterjadian penyakit (\%), $\mathrm{n}=$ Jumlah tanaman terserang, $\mathrm{N}=$ Jumlah seluruh tanaman yang diamati.

Selanjutnya keparahan penyakit dihitung dengan menggunakan skor atau skala penyakit yang terdiri dari 5 kategori tingkat serangan (Tabel 1) (Ginting, 2013). Semakin tinggi tingkat serangan penyakit maka semakin tinggi skor yang diberikan dan semakin rendah tingkat serangan maka semakin rendah skor yang diberikan.

Setelah mengetahui skor semua sampel daun, keparahan penyakit dapat dihitung dengan menggunakan rumus sebagai berikut:

$$
\mathrm{PP}=\frac{\sum(n x v)}{N x V} X 100 \%
$$

Keterangan: $\mathrm{PP}=$ Keparahan penyakit $(\%)$, $\mathrm{n}=$ Jumlah daun dengan skor tertentu, $\mathrm{v}=$ Nilai skor tiap kategori serangan, $\mathrm{N}=$ Jumlah daun yang diamati (sampel), dan $\mathrm{V}=$ Skor atau skala tertinggi.

Variabel pengamatan selanjutnya yaitu tinggi tanaman dan jumlah daun tanaman jagung. Tinggi tanaman diukur dari permukaan tanah hingga ujung daun tertinggi tanaman dengan mengunakan meteran. Pengukuran dilakukan mulai dari $1 \mathrm{mst}$, 2 mst, 3 mst, 4 mst dan 5 mst (minggu setelah tanam). Selanjutnya pengamatan jumlah daun dilakukan dengan menghitung jumlah daun tanaman jagung. Pengamatan ini dilakukan setiap 7 hari sekali pada setiap polybag, dihitung sejak minggu pertama setelah tanam.

Variabel pengamatan yang paling terakhir diamati adalah bobot kering brangkasan yang dihitung pada 43 hst (hari setelah tanam). Bobot kering brangkasan ditimbang dengan cara sebagai berikut: tanaman jagung dicabut dari media tanam kemudian dibersihkan dari kotoran yang melekat seperti tanah. Selanjutnya brangkasan dipotongpotong dengan dipisahkan bagian akar, batang dan daun. Kemudian dimasukkan ke dalam amplop yang berbeda sesuai dari bagian tanaman. Selanjutnya dioven dengan suhu 80 ÚC selama 4 hari sampai bobot brangkasan telah konstan.

Data yang diperoleh dari hasil pengamatan dianalisis secara statistik; homogenitas data diuji dengan uji Barlett; dan aditifitas data diuji dengan uji Tukey. Data dianalisis ragam (anova), apabila hasilnya nyata maka dilanjutkan dengan Uji Beda Nyata Terkecil (BNT) pada á $=5 \%$.

\section{HASIL DAN PEMBAHASAN}

\subsection{Gejala Penyakit Bulai}

Berdasarkan hasil pengamatan, gejala awal penyakit bulai pada tanaman jagung dapat dilihat pada hari ke 6 hsi (hari setelah inokulasi). Gejala awal penyakit bulai berupa adanya garis - garis putih sejajar dengan tulang daun (Gambar 3a). Selanjutnya, gejala klorosis muncul ke seluruh permukaan daun (Gambar 3b). Pada bagian permukaan atas dan bawah daun jagung jika dilihat pada pagi hari terdapat konidia berwarna seperti tepung.

\subsection{Masa Inkubasi}

Masa inkubasi merupakan selang waktu antara inokulasi sampai munculnya gejala untuk pertama kalinya pada tanaman. Pada hasil analisis nilai tengah perlakuan mefenoksam dan Trichoderma sp. tidak berpengaruh nyata terhadap masa inkubasi penyakit bulai. Selain itu, tidak terjadi interaksi antarperlakuan fungisida berbahan aktif

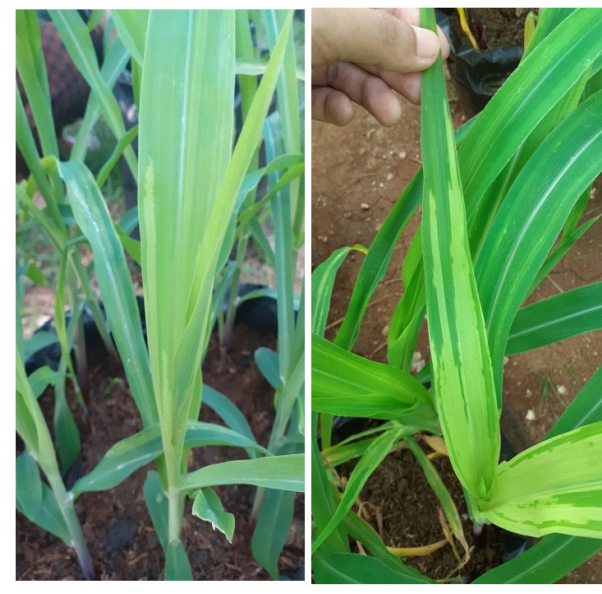

Gambar 2. Gejala dan Tanda Penyakit Bulai (Peronosclerospora sp.). (A) Gejala Klorosis Awal (B) Gejala Klorosis di Seluruh Permukaan Daun. 
mefenoksam dan Trichoderma sp. Data masa inkubasi disajikan pada Gambar 3.

\subsection{Keterjadian Penyakit Bulai}

Keterjadian penyakit merupakan persentase tanaman yang terserang patogen dalam suatu lahan. Berdasarkan hasil analisis nilai tengah (Tabel2) perlakuan fungisida dapat menekan keterjadian penyakit bulai, sedangkan perlakuan menggunakan Trichoderma sp. tidak berpengaruh nyata terhadap keterjadian penyakit bulai. Selain itu, interaksi antara perlakuan mefenoksam dan Trichoderma sp. tidak berpengaruh nyata terhadap keterjadian penyakit bulai.

\subsection{Keparahan Penyakit Bulai}

Keparahan penyakit merupakan gambaran luas wilayah yang terserang penyakit dibandingkan dengan keseluruhan daun. Berdasarkan hasil analisis nilai tengah (Tabel 3) perlakuan perlakuan fungisida dapat menekan keparahan penyakit bulai, sedangkan perlakuan menggunakan Trichoderma sp. tidak berpengaruh nyata terhadap keparahan penyakit bulai. Selain itu, interaksi antara perlakuan mefenoksam dan Trichoderma sp. tidak berpengaruh nyata terhadap keparahan penyakit bulai.

\subsection{Tinggi Tanaman, Jumlah Daun, dan Bobot Kering Tanaman Jagung}

Berdasarkan hasil analisis nilai tengah, perlakuan fungisida dan Trichoderma sp. tidak berpengaruh nyata terhadap tinggi dan jumlah daun tanaman. Selain itu, interaksi antara perlakuan mefenoksam dan Trichoderma sp. tidak berpengaruh nyata terhadap tinggi dan jumlah daun jagung.

Selanjutnya, pada (Gambar 4) menunjukkan tinggi tanaman jagung dari minggu pertama sampai minggu ke enam dengan berbagai perlakuan. Selain itu, pada (Gambar 5) menunjukkan jumlah daun tanaman jagung dari minggu pertama sampai minggu ke enam.

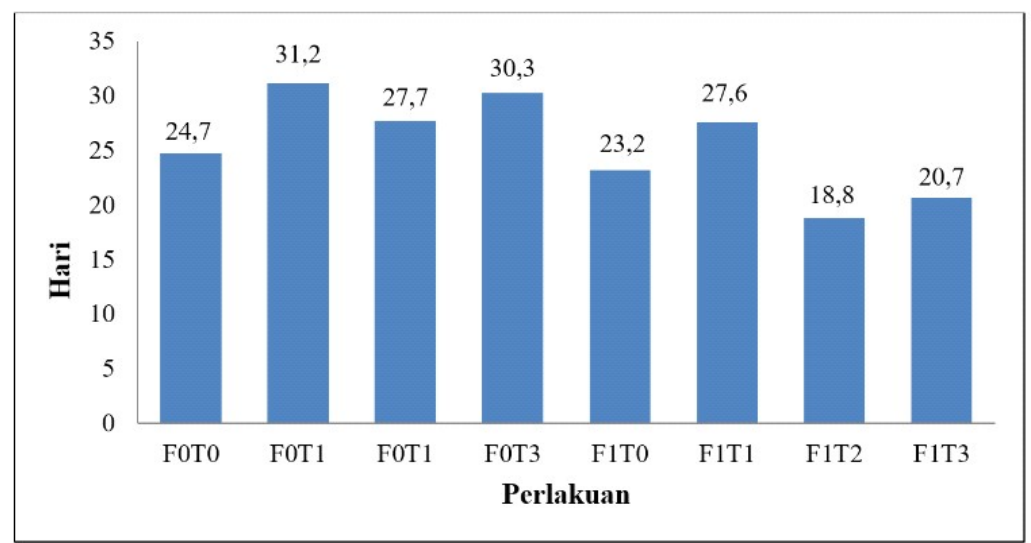

Gambar 3. Diagram Batang Rerata Masa Inkubasi Penyakit Bulai pada Tanaman Jagung yang Diberi Perlakuan Mefenoksam dan Trichoderma sp.

Keterangan: $\mathrm{F}_{0}=$ Tanpa fungisida, $\mathrm{F}_{1}=$ Menggunakan fungisida mefenoksam, $\mathrm{T}_{0}=$ Tanpa Trichoderma $\mathrm{sp}$, $\mathrm{T}_{1}=$ Trichoderma $\mathrm{sp}$. kerapatan spora $10^{5} \mathrm{spora} / \mathrm{ml}, \mathrm{T}_{2}=$ Trichoderma $\mathrm{sp}$. kerapatan $10^{6} \mathrm{spora} / \mathrm{ml}$ dan $\mathrm{T}_{3}=$ Trichoderma sp. kerapatan $10^{7} \mathrm{spora} / \mathrm{ml}$.

Tabel 2. Keterjadian Penyakit Bulai pada Tanaman Jagung yang Diberi Perlakukan Mefenoksam

\begin{tabular}{cccccc}
\hline \multirow{2}{*}{ Perlakuan } & \multicolumn{5}{c}{ Keterjadian Penyakit (\%) } \\
\cline { 2 - 6 } & $\begin{array}{c}7 \text { hsi } \\
\text { Trans }(\sqrt{ }(\mathrm{x}+0,5)\end{array}$ & 14 hsi & 21 hsi & 28 hsi & \multirow{2}{*}{35 hsi } \\
\hline F0 (Tanpa mefenoksam) & $2,17 \mathrm{a}$ & $55,83 \mathrm{a}$ & $71,68 \mathrm{a}$ & $71,67 \mathrm{a}$ & $74,17 \mathrm{a}$ \\
F1 (Dengan Mefenoksam) & $0,71 \mathrm{~b}$ & $22,5 \mathrm{~b}$ & $43,33 \mathrm{~b}$ & $46,67 \mathrm{~b}$ & $49,33 \mathrm{~b}$ \\
\hline BNT 5\% & 0,96 & 9,14 & 14,03 & 14,57 & 14,17 \\
\hline
\end{tabular}

Keterangan : Nilai tengah yang diikuti huruf yang sama menunjukkan tidak berbeda nyata padauji BNT (5\%), hsi= hari setelah inokulasi. 
Tabel 3. Keparahan Penyakit Bulai pada Tanaman Jagung yang Diberi Perlakukan Mefenoksam

\begin{tabular}{cccccc}
\hline \multirow{2}{*}{ Perlakuan } & \multicolumn{5}{c}{ Keparahan Penyakit (\%) } \\
\cline { 2 - 6 } & $\begin{array}{c}7 \mathrm{hsi} \\
\text { Trans }(\sqrt{ }(\mathrm{x}+0,5)\end{array}$ & $14 \mathrm{hsi}$ & $21 \mathrm{hsi}$ & $28 \mathrm{hsi}$ & \multirow{2}{*}{$35 \mathrm{hsi}$} \\
\hline F0 (Tanpa Mefenoksam) & $1,32 \mathrm{a}$ & $21,20 \mathrm{a}$ & $39,80 \mathrm{a}$ & $52,02 \mathrm{a}$ & $59,72 \mathrm{a}$ \\
F1 (Dengan Mefenoksam) & $0,71 \mathrm{~b}$ & $8,91 \mathrm{~b}$ & $20,76 \mathrm{~b}$ & $29,97 \mathrm{~b}$ & $33,84 \mathrm{~b}$ \\
\hline BNT 5\% & 0,42 & 6,42 & 9,56 & 11,50 & 12,12 \\
\hline
\end{tabular}

Keterangan : Nilai tengah yang diikuti huruf yang sama menunjukkan tidak berbeda nyata padauji BNT (5\%), hsi= hari setelah inokulasi.

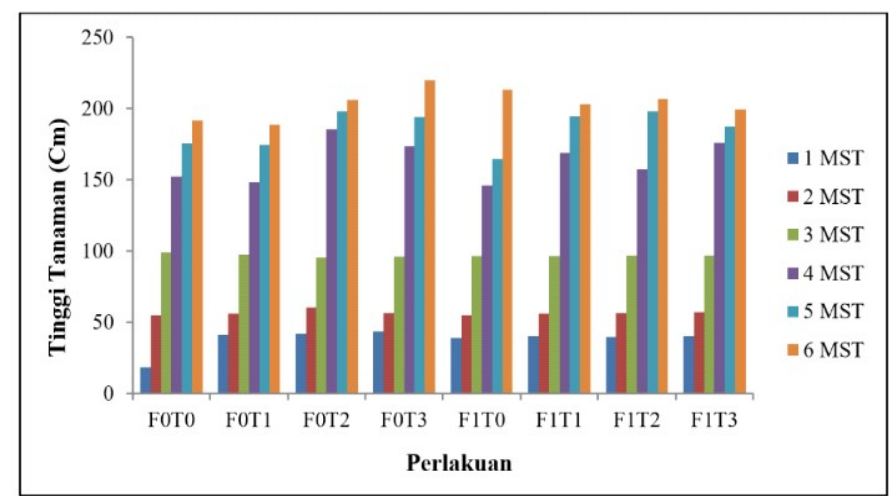

Gambar 4. Diagram Batang Rerata Tinggi Tanaman Jagung yang Diberi Perlakuan Mefenoksam dan Trichoderma $\mathrm{sp}$.

Keterangan: $\mathrm{F}_{0}=$ Tanpa fungisida, $\mathrm{F}_{1}=$ Menggunakan fungisida mefenoksam, $\mathrm{T}_{0}=$ Tanpa Trichoderma $\mathrm{sp}$, $\mathrm{T}_{1}=$ Trichoderma sp. kerapatan spora $10^{5} \mathrm{spora} / \mathrm{ml}, \mathrm{T}_{2}=$ Trichoderma sp. kerapatan $10^{6} \mathrm{spora} / \mathrm{ml}$ dan $\mathrm{T}_{3}=$ Trichoderma sp. kerapatan $10^{7}$ spora/ml.

Pada variabel pengamatan bobot kering brangkasan tajuk dan akar, hasil analisis nilai tengah menjelaskan bahwa perlakuan mefenoksam dan Trichoderma sp. tidak berpengaruh nyata terhadap bobot kering brangkasan penyakit bulai. Selain itu, tidak terjadi interaksi antarperlakuan fungisida berbahan aktif mefenoksam dan Trichoderma sp.

Pada penelitian ini penyakit bulai pertama muncul pada 6 hsi atau pada saat tanaman jagung berumur 13 hst. Tanda penyakit bulai yang terdapat struktur patogen menyerupai tepung di bawah permukaan daun pada tanaman jagung. Selanjutnya, pada bagian daun jagung terdapat bercak - bercak klorotis, lalu bercak tersebut berkembang menjadi garis sejajar pada tulang daun (Gambar 3b). Menurut Semangun (2004), gejala penyakit bulai pada tanaman jagung dimulai dengan munculnya bercak klorotis yang memanjang sejajar dengan tulang daun dengan batas yang jelas dan terdapat tanda penyakit berupa tepung di bawah permukaan daun.

Perlakuan dengan mefenoksam dapat menekan keterjadian dan keparahan penyakit bulai selama penelitian dilakukan. Aplikasi mefenoksam dapat menekan penyakit bulai pada tanaman jagung (Korlina dan Amir, 2015). Selain dapat mengendalikan penyakit bulai pada tanaman jagung, mefenoksam dapat mengendalikan penyakit yang disebabkan oleh patogen tular tanah lainnya. Menurut Hu et al. (2010) mefenoksam dilaporkan dapat mengendalikan Phytophthora cinnamoni pada pembibitan tanaman hias di Virginia, USA. Aktivitas fungisida bahan aktif mefenoksam dengan menghambat pertumbuhan miselium dan sporulasi patogen. Cara kerja spesifik bahan aktif fungisida ini dengan menghambat secara selektif sintesis RNA ribosom sehingga dapat mempengaruhi aktivitas polimerase RNA.

Tingginya intensitas serangan pada tanaman jagung dapat disebabkan oleh berbagai faktor, antara lain varietas tersebut tidak memiliki mekanisme ketahanan yang baik, sehingga menjadi rentan terhadap penyakit bulai, patogen yang menyerang merupakan patogen yang sangat virulen, dan kondisi lingkungan yang lembab saat penelitian berlangsung (Korlina dan Amir, 2015). 


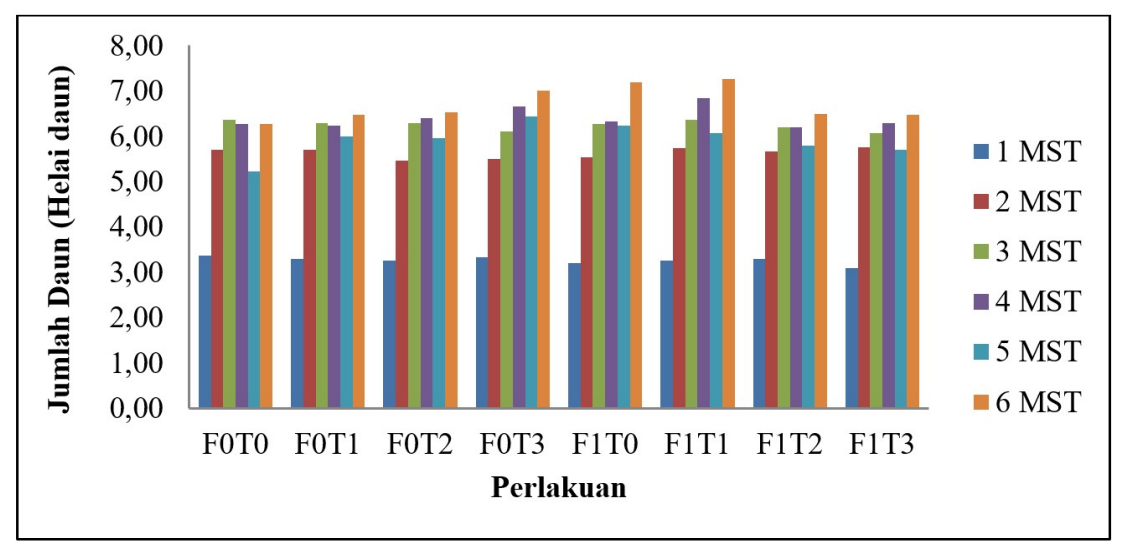

Gambar 5. Diagram Batang Rerata Jumlah Daun Tanaman Jagung yang Diberi Perlakuan Mefenoksam dan Trichoderma sp.

Keterangan: $\mathrm{F}_{0}=$ Tanpa fungisida, $\mathrm{F}_{1}=$ Menggunakan fungisida mefenoksam, $\mathrm{T}_{0}=$ Tanpa Trichoderma $\mathrm{sp}$, $\mathrm{T}_{1}=$ Trichoderma $\mathrm{sp}$. kerapatan spora $10^{5} \mathrm{spora} / \mathrm{ml}, \mathrm{T}_{2}=$ Trichoderma $\mathrm{sp}$. kerapatan $10^{6} \mathrm{spora} / \mathrm{ml}$ dan $\mathrm{T}_{3}=$ Trichoderma sp. kerapatan $10^{7} \mathrm{spora} / \mathrm{ml}$.

Menurut Hikmawati dkk. (2011), perkembangan dan penyebaran penyakit bulai sangat dipengaruhi oleh tersedianya inokulum dan kelembaban, terutama kelembaban dimalam hari.

Perlakuan Trichoderma sp. tidak berpengaruh nyata terhadap masa inkubasi, keterjadian penyakit, keparahan penyakit bulai, tinggi tanaman, dan jumlah daun tanaman jagung. Menurut Baihaqi (2013), menjelaskan bahwa pertumbuhan Trichoderma sp. yang kurang, sumber makanan dan kelembaban udara yang relatif berfluktuasi dapat menjadi penyebab menurunnya efisiensi aplikasi Trichoderma sp.

Faktor lain yang diduga dapat menyebabkan Trichoderma sp. tidak dapat mengendalikan penyakit bulai adalah terganggunya pertumbuhan Trichoderma sp. karena aplikasi fungisida mefenkosam pada benih. Menurut Gomez et al. (2015), mefenoksam dapat membunuh atau menghambat aktivitas produktivitas kelompokjamur yang berada di dalam tanah. Hal ini dapat menyebabkan terganggunya pertumbuhan Trichoderma sp. dan mikroorganisme mengguntungkan yang ada di dalam tanah.

Ketidakberhasilan Trichoderma sp. dalam menekan penyakit bulai dapat disebabkan oleh kurangnya konsentrasi Trichoderma sp. yang diaplikasikan dan tingkat serangan patogen yang berat dari inokulasi patogen secara alami yang disebabkan faktor iklim, seperti kelembaban dan suhu udara serta didukung oleh penambahan inokulasi patogen secara buatan (Ivayani dkk., 2018). Menurut Dini (2016) ketidakberhasilan efikasi formulasi Trichoderma sp. sebagai pengendali jamur tular tanah ditentukan oleh berberapa faktor diantaranya kelembaban tanah, jenis tanah, metode dan waktu aplikasinya.

\section{KESIMPULAN}

Berdasarkan hasil penelitian dapat disimpulkan bahwa mefenoksam dapat menekan keterjadian penyakit bulai dan keparahan penyakit bulai. Selain itu, Trichoderma sp. isolat Gunung Sugih, Lampung Tengah tidak berpengaruh terhadap penyakit bulai dan pertumbuhan tanaman jagung dan tidak ada interaksi antar perlakuan mefenoksam dan Trichoderma $\mathrm{sp}$.

\section{DAFTAR PUSTAKA}

Badan Pusat Statistik. 2017. Produksi Jagung Menurut Provinsi (ton), 2010 - 2017. Diakses15 Februari 2021, pukul 20.00 WIB. https://lampung.bps.go.id/

Baihaqi, A., Nawawi, M., dan Abadi, A.L. 2013. Teknik aplikasi Trichoderma sp. terhadap pertumbuhan dan hasil tanaman kentang (Solanum tuberosum L.). Jurnal Produksi tanaman. 1 (3) : $30-39$.

Burhanuddin. 2009. Fungisida metalaksil tidak efektif menekan penyakit bulai (Peronosclerospora maydis) di Kalimantan Barat dan alternatif pengendaliannya. Prosiding Seminar Nasional Serealia 2009. Balai Penelitian Tanaman Serealia. hal 395 - 399. 
Dini. P.Y. 2016. Pengaruh lama penyimpanan beberapa formulasi Trichoderma viride terhadap viabilitas dan daya antagonisnya dalam menekan Fusarium oxysporum $F$. $s p$ cubense (Foc) secara in vitro. Skripsi. Universitas Andalas.

Ginting, C. 2013. Ilmu Penyakit Tumbuhan Konsep dan Aplikasi. Lembaga Penelitian Universitas Lampung. Bandar Lampung.

Gomez, I., Martinez, A.M.G., Osta, P., Parrado, J., and Tejada, M. 2015. Effect of mefenoxam fungicide on soil biochemichal properties. Bull Environ Contam Toxicol. 94 : $622-626$.

Harman, G.E., Petzoldt, R., Comis, A. and Chen, J. 2004. Interactions between Trichoderma harzianum strain T22 and maize inbred line Mo17 and effects of these interactions on diseases caused by Pythium ultimum and Colletotrichum graminicola. Phytopathology. 94 (2) : 147-153.

Hikmawati, Kuswinanti, T., Melina, dan Pabendon, M. B. 2011. Karakterisasi morfologi Peronosclerospora sp., penyebab penyakit bulai pada tanaman jagung, dari beberapa daerah di Indonesia. Badan Penelitian dan Pengembangan Pertanian Balai Penelitan Tanaman Serealia Maros. Balai Penelitian Tanaman Serealia.Maros.
Hu, J., Hong, C., Stomberg, E. L., and Moorman, G. W. 2010. Mefenoxam sensitivity in Phytophthora cinnamomi isolates. Plant Dis. 94:39-44.

Ivayani, Faishol F., dan Prasetyo J. (2018). Efektivitas beberapa isolat Trichoderma sp. terhadap keterjadian penyakit bulai yang disebabkan oleh Peronosclerospora maydis dan pertumbuhan tanaman jagung (Zea mays). Jurnal Pertanian Terapan. 18 (1): 39-45.

Jatnika, W., Abadi, A. L., dan Aini, L. Q. 2013. Pengaruh aplikasi Bacillus sp. dan Pseudomonas sp. terhadap perkembangan penyakit bulai yang disebabkan oleh jamur Peronosclerospora maydis pada tanaman jagung. Jurnal HPT. 1(4): 19-29.

Korlina, E. dan Amir, A.M. 2015. Efektivitas jenis fungisida terhadap penyakit bulai (Peronosclerospora maydis) pada jagung. Prosiding Seminar Nasional. Balai Pengkajian Teknologi Jawa Timur.

Muhammad, N. 2014. Strategi pengembangan agribisnis tanaman jagung pada dinas pertanian kabupaten halmaherea utara. Jurnal Ilmiah Agribisnis dan Perikanan (agrikan UMMU- Ternate).7(1): 58-65.

Semangun, H. 2004. Penyakit- Penyakit Tanaman Pangan di Indonesia. UGM Press. Yogyakarta. $429 \mathrm{hlm}$. 